\title{
FAKTOR-FAKTOR YANG BERPENGARUH TERHADAP ANGGARAN PENDAPATAN DAN BELANJA DAERAH (APBD) BERBASIS KINERJA PADA PEMERINTAH KOTA BITUNG PROVINSI SULAWESI UTARA
}

\author{
Anestasye Agnes Woinalang, Jullie J. Sondakh, Ventje Ilat \\ (Email : ag17es@ymail.com)
}

\begin{abstract}
Public demands to create good governance such as accountability for local financial management drives government to increase their effort in achieve successful implementation of performance based budgeting by clearly ensure the related between expenditure allocation and performance with efficiency and effectiveness. This research aims to analyze the affecting of budgeting integration with planning and organizing, comprehensive planning and budgeting system and monitoring and evaluating of APBD simultaneous and partially.

This study uses samples for 70 people to test the hypothesis of budgeting integration with planning and organizing, comprehensive planning and budgeting system and monitoring and evaluating of APBD simultaneous and partially used $F$ test and $T$ test with multiple linear analysis method. The result prove that budgeting integration with planning and organizing, comprehensive planning and budgeting system and monitoring and evaluating simultaneous affect significantly to performance based budgeting of APBD. Budgetting integration with planning and organizing and monitoring and evaluating partially affect significantly to performance based budgeting of $A P B D$
\end{abstract}

Keywords : APBD, Reinventing Government, Agency, Kebijakan

\section{PENDAHULUAN}

Perubahan cara pandang masyarakat di Indonesia mendorong pemerintah untuk melakukan reformasi desentralisasi yang telah menjadi fenomena bagi negara-negara di dunia. Pasca reformasi, banyak tuntutan daerah untuk meminta kewenangan lebih besar dalam mengelola keuangan di daerahnya masing-masing. Hal ini terjadi sebagai efek dari desentralisasi berbagai macam urusan pemerintahan yang selama ini dipegang oleh pemerintah pusat menjadi kewenangan dan tanggungjawab daerah, termasuk dalam hal keuangan untuk membangun good governance. Reformasi di bidang keuangan ditandai dengan lahirnya tiga paket undang-undang, yaitu Undang-Undang No. 17 Tahun 2003 tentang Keuangan Negara, Undang-Undang No. 1 tahun 2004 tentang Perbendaharaan Negara dan Undang-Undang No. 15 Tahun 2004 tentang Pemeriksaan Pengelolaan dan Tanggungjawab Keuangan Negara. Ketiga UU tersebut memulai era baru dalam pengelolaan keuangan negara, yaitu dari administrasi keuangan (financial administration) menjadi pengelolaan keuangan (financial management). Salah satu wujud perubahan adalah penerapan anggaran berbasis kinerja (performance based budget). Pengganggaran berbasis kinerja merupakan teknik penganggaran yang mengikuti pendekatan new public management. Pendekatan yang dilakukan dengan sistem ini adalah dengan memperjelas keterkaitan alokasi pendanaan dan kinerja serta memperhatikan efisiensi dan efektivitas dalam pencapaian kinerja. Anggaran Berbasis Kinerja (ABK) merupakan proses penyusunan Anggaran Pendapatan Belanja Daerah (APBD) yang diberlakukan dengan harapan dapat mendorong proses tata kelola pemerintahan yang lebih baik (Utomo et.al.2007). Madjid dan Ashari 2013, menyatakan bahwa pemerintah di Indonesia telah melaksanakan anggaran berbasis kinerja tetapi belum utuh dan konsisten. Pada kenyataannya penerapan performance 
based budgeting hanya diikuti daerah pada tingkat perubahan teknis dan format, namun perubahan paradigma belum banyak terjadi (Rahayu et.al.2007). Utari, 2009 menyatakan bahwa penyusunan anggaran berbasis kinerja pada Kabupaten Temanggung ditemukan beberapa kendala dan hambatan antara lain, 1) struktur SKPD belum memberi ruang yang cukup bagi penyusunan perencanaan dan penganggaran secara terintegrasi, 2) tim anggaran belum terlibat secara penuh pada setiap tahapan perencanaan, 3) kurangnya pengetahuan, pemahaman dan juga motivasi pegawai untuk menerapkan anggaran kinerja secara optimal, 4) keterbatasan anggaran daerah. Selanjutnya Hananto et.al. (2013) menyimpulkan bahwa Universitas Negeri Semarang (UNS) telah menetapkan sistem anggaran berbasis kinerja, namun belum efektif walaupun UNS telah memiliki sumberdaya untuk dapat menerapkan anggaran berbasis kinerja yang optimal. Sistem perencanaan, penganggaran, pelaporan dan pertanggungjawaban belum terintegrasi, sehingga antara laporan kinerja operasional dan laporan keuangan belum berasal dari satu kesatuan sistem yang terintegrasi. Kota Bitung adalah salah satu daerah otonomi di Propinsi Sulawesi Utara dengan pemerintahnya yang dipimpin oleh Walikota dan Wakil Walikota yang mempunyai 44 SKPD sebagai penunjang kinerja pemerintahan. Dalam hal penganggaran, Pemerintah Kota Bitung telah menyesuaikan struktur APBD secara bertahap sesuai dengan peraturan perundangan yang berlaku yaitu Undang-Undang No. 17 Tahun 2003 tentang Keuangan Negara yang menyatakan bahwa setiap instansi pemerintah diwajibkan untuk merancang dan mengelola anggaran berbasis kinerja. Dalam Better Practice Guide Penganggaran Berbasis Kinerja oleh Kementerian Keuangan Republik Indonesia edisi 2014, karakteristik penganggaran yang efektif, yaitu : 1) Integrasi proses penganggaran dengan perencanaan dan tata kelola organisasi; 2) perencanaan dan penganggaran yang komprehensif; 3) monitoring dan evaluasi. Tujuan penelitian apakah integrasi penganggaran dengan perencanaan dan tata kelola organisasi, perencanaan dan penganggaran yang komprehensif, monitoring dan evaluasi berpengaruh terhadap penyusunan Anggaran Pendapatan Belanja Daerah (APBD) berbasis kinerja pada Pemerintah Kota Bitung Provinsi Sulawesi Utara.

\section{TINJAUAN PUSTAKA \\ Teori Reinventing Government}

Teori ini dikemukakan oleh David T. Osborne dan Ted Gaebler pada tahun 1992 mengemukakan pandangannya yang berisi tentang reformasi di bidang pemerintahan dengan menggunakan Reiventing Government Salah satu perspektif dalam reinventing government ini adalah Mission Driven Budgeting, atau anggaran yang digerakan oleh tujuan. Jadi dengan perspektif ini yang jadi pokok dari anggaran adalah tujuannya atau misi anggaran tersebut dimanfaatkan.

\section{Teori Agency}

Jensen dan Meckling (1976) menyatakan bahwa hubungan keagenan adalah sebuah hubungan kontrak antara manajer (agent) dengan pemegang saham (principal). Hubungan tersebut terkadang menimbulkan masalah diantara kedua pihak yang melakukan kontrak. Hubungan keagenan di pemerintahan antara eksekutif dan legislatif, eksekutif (pemerintah) adalah agent dan legislatif (DPRD) adalah principal. Sebelum penyusunan APBD dilakukan, terlebih dahulu dibuat kesepakatan antara eksekutif dan legislatif tentang arah dan kebijakan umum serta prioritas anggaran, yang akan menjadi pedoman dalam penyusunan APBD. Eksekutif membuat rancangan APBD yang kemudian diserahkan kepada legislatif untuk dipelajari dan dibahas bersama-sama sebelum ditetapkan sebagai peraturan daerah (perda). 
Dalam perspektif keagenan hal ini merupakan bentuk kontrak (incomplete contract) yang menjadi alat bagi legislatif untuk mengawasi pelaksanaan anggaran oleh eksekutif.

\section{Teori Kebijakan}

Menurut Jones (1997) kebijakan merupakan keputusan tetap yang dicirikan oleh pelaku bersifat konsisten dan pengulangan (repetiveness) tingkah laku dari mereka yang membuat dan dari mereka yang mematuhi keputusan tersebut. Dengan kata lain keputusan tersebut memiliki dasar hukum yang kuat sehingga harus dibuat secara konsisten serta harus dilaksanakan oleh semua pihak yang berada di dalam ruang lingkup berlakunya kebijakan tersebut, termasuk diantaranya pihak-pihak yang membuat kebijakan. Dalam melaksanakan kebijakan publik tadi perlu dikontrol dan dievaluasi, sejauh mana kinerja mereka dalam melaksanakan apa yang menjadi tugas dan fungsinya masing-masing..

\section{Implementasi Kebijakan}

George C. Edward III. Menurut Edwards, ada empat variabel dalam implementasi kebijakan publik yaitu Komunikasi (communications), Sumberdaya (resources), Sikap (dispositions atau attitudes) dan struktur birokrasi (bureucratic structure). Keempat faktor tersebut harus dilaksanakan secara simultan karena antara satu dengan yang lainnya memiliki hubungan yang erat.

\section{Teori Anggaran}

Negara/daerah sebagai suatu entitas sektor publik juga memanfaatkan anggaran sebagai alat untuk mencapai tujuan. Sebagaimana disebutkan dalam teori kebijakan, bahwa dalam proses penyusunan dan implementasi kebijakan tersebut mengandung dua ranah yaitu ranah administrasi dan ranah politik. Demikian juga dengan kebijakan anggaran sangat dipengaruhi dengan perubahan-perubahan yang terjadi di lingkungan politik, begitu banyak kepentingan yang harus dialokasikan menurut keinginan pihak-pihak tertentu yang masing-masing ingin diprioritaskan. Menurut Shah dan Shen, anggaran publik dibutuhkan untuk memenuhi beberapa fungsi sesuai dengan mandat yang diberikan kepada pemerintah. Dibutuhkan perencanaan jangka panjang, pengendalian keuangan, pelaksanaan yang efisien, serta penyediaan sarana dan prasarana untuk mempertanggungjawabkan kinerja pemerintah terhadap masyarakat.

\section{Anggaran Pendapatan dan Belanja Daerah (APBD)}

Pengertian Anggaran Pendapatan dan Belanja Daerah (APBD) menurut Bastian (2006) adalah merupakan pengejawantahan rencana kerja Pemerintah Daerah dalam bentuk satuan uang untuk kurun waktu satu tahun tahunan dan berorientasi pada tujuan kesejahteraan publik. APBD merupakan dasar pengelolaan keuangan daerah dalam satu tahun anggaran. APBD merupakan rencana pelaksanaan semua pendapatan daerah dan semua belanja daerah dalam rangka pelaksanaan desentralisasi dalam tahun anggaran tertentu. Pemungutan semua penerimaan daerah bertujuan untuk memenuhi target yang ditetapkan dalam APBD. Demikian pula semua pengeluaran daerah dan ikatan yang membebani daerah dalam rangka pelaksanaan desentralisasi dilakukan sesuai jumlah dan sasaran yang ditetapkan dalam APBD. Karena APBD merupakan dasar pengelolaan keuangan daerah, maka APBD menjadi dasar pula bagi kegiatan pengendalian, pemeriksaan dan pengawasan keuangan daerah.

\section{Proses Penyusunan APBD berbasis kinerja}

Tahapan penyusunan APBD berbasis kinerja seperti yang dijelaskan diatas, maka penerapan penganggaran berbasis kinerja lebih menekankan pada informasi kinerja atas pelaksanaan suatu program dan kegiatan serta dampak/hasilnya pada masyarakat luas. Dari tahapan siklus penganggaran berbasis kinerja yang harus dijalani, lebih disederhanakan menjadi : 1) penetapan sasaran strategis; 2) penetapan outcome program dan output kegiatan; 3) penetapan 
indikator kinerja utama program dan indikator kinerja kegiatan; 4) penetapan standar biaya; 5) penghitungan kebutuhan anggaran. Setelahnya untuk dapat menilai/menjamin efektivitas dan efisiennya penyusunan anggaran termasuk program dan kegiatan dalam pelaksanaan anggaran dibutuhkan pertanggungjawaban baik keuangan maupun kinerja kemudian ditindaklanjuti dengan proses monitoring dan evaluasi.

\section{Integrasi penganggaran dengan perencanaan dan tata kelola organisasi}

Perencanaan strategis adalah merupakan suatu proses merencanakan hasil dan strategi secara sistematis dan berkesinambungan dengan memperhitungkan potensi, peluang dan kendala yang mungkin ada/timbul (Tjandra, 2013). Guna menjabarkan rencana strategis yang disusun pemerintah daerah lebih lanjut harus membuat rencana kinerja tahunan, yang mencakup periode tahunan rencana strategis yang disusun. Di dalamnya, instansi pemerintah mendefinisikan seluruh sasaran strategis, kebijakan, program dan kegiatan yang akan diimplementasikan dalam satu tahun kegiatan. Rencana kinerja menjadi dasar penyusunan dan pengajuan anggaran berbasis kinerja.

\section{Perencanaan dan penganggaran yang komprehensif}

Dalam Better Practice Guide : Developing and Managing Internal Budget yang di published pada Australian National Audit Office 27 Juni 2008 yang menjelaskan bahwa menyusun dan melaksanakan proses/sistem penganggaran adalah langkah utama pada sebagian besar organisasi. Proses penyusunan dilakukan secara berkesinambungan sepanjang tahun dan melibatkan para pemangku kepentingan. Dengan demikian, agar proses penganggaran berjalan efektif maka dibutuhkan langkah-langkah sebagai berikut (Kementerian Keuangan RI, 2014) : 1) koordinasi dan perencanaan yang efektif; 2) pendekatan penganggaran yang efektif; 3) koordinasi dan quality assurance yang efektif.

\section{Monitoring dan Evaluasi}

Monitoring merupakan suatu penilaian secara berkesinambungan atas implementasi rencana program/kegiatan, terutama berkaitan dengan jadwal waktu yang telah disepakati, penggunaan sumber daya, serta kualitas yang telah direncanakan. Sedangkan evaluasi merupakan penilaian periodic atas suatu program/kegiatan, yang berkaitan dengan relevansi dari program/kegiatan tersebut, tingkat kinerjanya, efisien dan efektivitas, serta dampak yang terjadi, yang dikaitkan dengan tujuan dan sasaran yang telah direncanakan (Kementerian Keuangan, 2014). Keterkaitan antara monitoring dan evaluasi adalah laporan hasil monitoring biasanya akan digunakan sebagai sumber informasi dasar bagi pelaksanaan evaluasi.

\section{HIPOTESIS DAN MODEL}

Berdasarkan latar belakang, rumusan masalah, tinjauan pustaka dan kerangka konseptual, maka hipotesis penelitian dapat dikemukakan sebagai berikut.

Ha1 = Integrasi Penganggaran dengan perencanaan dan tata kelola organisasi berpengaruh signifikan terhadap Penyusunan APBD berbasis Kinerja

$\mathrm{Ha} 2=$ Perencanaan dan Penganggaran yang Komprehensif berpengaruh signifikan terhadap Penyusunan APBD berbasis Kinerja

$\mathrm{Ha3}=$ Montoring dan Evaluasi berpengaruh signifikan terhadap Penyusunan APBD berbasis Kinerja

Formulasi dari regresi linier berganda dalam penelitian ini dapat ditulis sebagai berikut:

dimana:

$$
\mathbf{Y}=\mathbf{a}+\boldsymbol{\beta}_{1} \mathbf{X}_{1}+\boldsymbol{\beta}_{2} \mathbf{X}_{2}+\boldsymbol{\beta}_{3} \mathbf{X}_{3}+e
$$

Y : Penyusunan APBD berbasis kinerja 
a : Nilai intersep (konstanta)

$\beta_{1}$ : koefisien regresi integrasi penganggaran dengan perencanaan dan tata kelola organisasi

$\beta_{2}$ : kofisien regresi perencanaan dengan penganggaran yang komprehensif

$\beta_{3}$ : koefisien regresi monitoring dan evaluasi

$\mathrm{X}_{1}$ : integrasi penganggaran dengan perencanaan dan tata kelola organisasi

$\mathrm{X}_{2}$ : perencanaan dengan penganggaran yang komprehensif

$\mathrm{X}_{3}$ : monitoring dan evaluasi

e : error

\section{METODE PENELITIAN}

Jenis dan Sumber Data

Dilihat dari sumber data, penelitian ini menggunakan sumber data primer dan data sekunder. Sumber data primer yaitu data diambil langsung dari sumber data (pengguna anggaran dan kepala sub bagian perencanaan/keuangan), yaitu hasil kuesioner dan interview. Sumber data sekunder yaitu RPJMD 2011-2016, RKPD 2015, KUA-PPAS 2015, RKA-SKPD 2015 dan LAKIP Kota Bitung 2015. Berdasarkan cara atau teknik pengumpulan data, penelitian ini menggunakan kuesioner dan interview. Menurut Sugiyono (2014), kuesioner adalah teknik pengumpulan data yang dilakukan dengan cara memberi seperangkat pertanyaan atau pernyataan tertulis kepada responden untuk dijawab. Kuesioner yang digunakan dalam penelitian ini merupakan kuesioner tertutup. Interview dalam penelitian ini hanya berupa pendampingan kepada populasi pada saat pengisian kuesioner untuk menjaga agar penelitian tidak bias. Populasi pada penelitian ini adalah personel yang terkait dengan proses penganggaran berbasis kinerja sebanyak 132 Orang dan yang menjadi sampel dalam penelitian ini sebanyak 70 orang untuk menguji hipotesis pengaruh faktor integrasi penganggaran dengan perencanaan dan tata kelola organisasi, perencanaan dan penganggaran yang komprehensif dan monitoring dan evaluasi terhadap penyusunan APBD secara simultan dan parsial digunakan Uji $\mathrm{F}$ dan Uji $\mathrm{t}$ dengan metode analisis linier berganda.

\section{Pengujian Hipotesis}

1. Uji Regresi Simultan (Uji F)

Uji F dilakukan untuk mengetahui pengaruh variabel-variabel independen secara simultan (bersama-sama) terhadap variabel dependen, dimana hipotesis statistiknya sebagai berikut:

На : $\beta_{1}, \beta_{2}, \beta, \neq 0$, berarti variabel independen berpengaruh signifikan terhadap variabel dependen apabila koefisien regresi variabel independen $\neq 0$.

Ho : $\beta_{1}, \beta_{2}, \beta_{3}=0$, berarti variabel independen tidak berpengaruh signifikan terhadap variabel dependen apabila koefisien regresi variabel independen $=0$.

2. Uji Regresi Parsial (Uji t)

Uji t dilakukan untuk mengetahui besarnya pengaruh masing-masing variabel independen secara individual terhadap variabel dependen, dimana hipotesis statistiknya sebagai berikut:

Hipotesis 1 : Integrasi penganggaran dengan perencanaan dan tata kelola organisasi berpengaruh signifikan terhadap penyusunan APBD berbasis kinerja.

Ha: $\beta_{1} \neq 0$, berarti integrasi penganggaran dengan perencanaan dan tata kelola organisasi berpengaruh signifikan terhadap penyusunan APBD berbasis kinerja. 
Ho: $\beta_{1}=0$, berarti integrasi penganggaran dengan perencanaan dan tata kelola organisasi tidak berpengaruh signifikan terhadap penyusunan APBD berbasis kinerja.

Hipotesis 2 : Perencanaan dan penganggaran yang komprehensif berpengaruh signifikan terhadap penyusunan APBD berbasis kinerja.

$\mathrm{Ha}: \beta_{2} \neq 0$, berarti perencanaan dan penganggaran yang komprehensif berpengaruh signifikan terhadap penyusunan APBD berbasis kinerja.

Ho: $\beta_{2}=0$, berarti perencanaan dan penganggaran yang komprehensif tidak berpengaruh signifikan terhadap penyusunan APBD berbasis kinerja.

Hipotesis 3 : Monitoring dan evaluasi berpengaruh signifikan terhadap penyusunan APBD berbasis kinerja.

Ha: $\beta_{3} \neq 0, \quad$ Monitoring dan evaluasi berpengaruh signifikan terhadap penyusunan APBD berbasis kinerja.

Ho: $\beta_{3}=0$, berarti Monitoring dan evaluasi tidak berpengaruh signifikan terhadap penyusunan APBD berbasis kinerja.

\section{HASIL ANALISIS DAN PEMBAHASAN}

Hasil Analisis Regresi

Tabel 1

Hasil Regresi Berganda

\begin{tabular}{|c|c|c|c|c|c|c|}
\hline & \multirow{2}{*}{ Model } & \multicolumn{2}{|c|}{$\begin{array}{l}\text { Unstandardized } \\
\text { Coefficients }\end{array}$} & \multirow{2}{*}{$\begin{array}{c}\begin{array}{c}\text { Standardized } \\
\text { Coefficients }\end{array} \\
\text { Beta }\end{array}$} & \multirow{2}{*}{$\mathbf{t}$} & \multirow{2}{*}{ Sig. } \\
\hline & & B & $\begin{array}{l}\text { Std. } \\
\text { Error }\end{array}$ & & & \\
\hline \multirow[t]{4}{*}{1} & (Constant) & 1,565 & 4,441 & & ,352 & ,726 \\
\hline & $\begin{array}{l}\text { Integrasi penganggaran } \\
\text { dengan perencanaan dan tata } \\
\text { kelola organisasi }\end{array}$ & ,404 & ,070 & ,430 & 5,816 & ,000 \\
\hline & $\begin{array}{l}\text { Perencanaan dan } \\
\text { penganggaran yang } \\
\text { komprehensif }\end{array}$ & ,048 & ,077 &, 043 & ,626 & ,534 \\
\hline & Monitoring dan evaluasi & ,746 & , 102 & ,552 & 7,307 & ,000 \\
\hline
\end{tabular}

a. Dependent Variable: Penyusunan APBD berbasis kinerja

Sumber: Hasil Olah data dengan SPSS

Berdasarkan tabel 1, diperoleh persamaan regresi berganda sebagai berikut:

$$
Y=1.565+0,404 X_{1}+0,048 X_{2}+0,746 X_{3}+e
$$

Persamaan regresi berganda di atas dapat dijelaskan sebagai berikut.

a. Penyusunan APBD berbasis kinerja pada Pemerintah Kota Bitung (Y) berhubungan positif atau searah dengan integrasi penganggaran dengan perencanaan dan tata kelola organisasi (X1), perencanaan dan penganggaran yang komprehensif (X2), dan monitoring dan evaluasi (X3).

b. Model penelitiannya untuk integrasi penganggaran dengan perencanaan dan tata kelola organisasi menunjukkan bahwa integrasi penganggaran dengan perencanaan dan tata kelola organisasi memiliki hubungan searah terhadap penyusunan APBD berbasis kinerja dilihat dari nilai koefisien regresi sebesar 0,404 . Hal ini menunjukan bahwa semakin terintegrasinya 
penganggaran dengan perencanaan dan tata kelola organisasi maka penyusunan APBD berbasis kinerja semakin baik.

c. Model penelitiannya untuk perencanaan dan penganggaran yang komprehensif menunjukkan bahwa perencanaan dan penganggaran yang komprehensif memiliki hubungan searah terhadap penyusunan APBD berbasis kinerja dilihat dari nilai koefisien regresi sebesar 0,048. Hal ini menunjukkan bahwa dengan adanya perencanaan dan penganggaran yang komprehensif proses penyusunan APBD berbasis kinerja akan semakin baik.

d. Model penelitiannya untuk monitoring dan evaluasi menunjukkan bahwa monitoring dan evaluasi memiliki hubungan searah terhadap penyusunan APBD berbasis kinerja dilihat dari nilai koefisien regresi sebesar 0,746 . Hal ini menunjukkan bahwa dengan dilaksanakannya monitoring dan evaluasi maka proses penyusunan APBD berbasis kinerja akan semakin baik setiap tahunnya.

e. Nilai intersep sebesar 1,565 menunjukkan bahwa apabila integrasi penganggaran dengan perencanaan dan tata kelola organisasi, perencanaan dan penganggaran yang komprehensif dan monitoring dan evaluasi dianggap konstan, maka penyusunan APBD berbasis kinerja akan meningkat sebesar 1,565 satuan.

\section{PEMBAHASAN}

Pengaruh integrasi penganggaran dengan perencanaan dan tata kelola organisasi terhadap penyusunan APBD Berbasis Kinerja

Hasil pengujian hipotesis pertama menunjukkan bahwa pada variabel integrasi penganggaran dengan perencanaan dan tata kelola organisasi, $t_{\text {hitung }}=5,816>t_{\text {tabel }}=1,99656$ sehingga integrasi penganggaran dengan perencanaan dan tata kelola organisasi berpengaruh signifikan terhadap penyusunan APBD berbasis kinerja pada Pemerintah Kota Bitung. Nilai koefisien regresi integrasi penganggaran dengan perencanaan dan tata kelola organisasi sebesar 0.404 menunjukkan bahwa jika adanya integrasi penganggaran dengan perencanaan dan tata kelola organisasi maka penyusunan APBD berbasis kinerja akan semakin baik. Hasil penelitian ini juga berarti bisa menggambarkan bagaimana Pemerintah Kota Bitung (agency) telah melibatkan masyarakat langsung maupun masyarakat melalui DPRD (principal) dalam proses penyusunan anggaran. Dengan adanya integrasi penganggaran dengan perencanaan dan tata kelola organisasi yang diukur dengan sumber informasi/data yang sama serta komitmen dari seluruh pihak yang berpengaruh signifikan terhadap proses penyusunan APDB di Kota Bitung maka Visi, Misi dari Kepala Daerah terpilih yang merupakan janji politiknya, bisa ditepati dan dilaksanakan oleh pemerintahannya. Pemerintah bisa menjadi agent yang baik dengan pelaksanaan penganggaran yang sesuai dengan kebijakan yang berlaku. Teori dasar penganggaran berbasis kinerja yaitu reinventing government dengan mission driven budgeting terpenuhi karena visi, misi, tujuan dan sasaran dalam proses perencanaan dapat didanai dengan baik melalui penganggaran program/kegiatan prioritas.

\section{Pengaruh perencanaan dan penganggaran yang komprehensif terhadap penyusunan APBD Berbasis Kinerja}

Hasil pengujian hipotesis kedua menunjukkan bahwa pada variabel sistem perencanaan dan penganggaran yang komprehensif, $t_{\text {hitung }}=0,534<\mathrm{t}_{\text {tabel }}=1,99656$ sehingga variabel ini tidak berpengaruh signifikan terhadap peyusunan APBD berbasis kinerja. Nilai koefisien regresi kompetensi hanya sebesar 0,048 menunjukkan bahwa dengan adanya perencanaan dan penganggaran yang komprehensif tidak berpengaruh signifikan untuk proses penyusunan APBD berbasis kinerja di Kota Bitung. Sesuai dengan teori reinventing government Osborne dan 
Gaebler (1992), diantaranya Mission driven Budgeting (anggaran yang digerakan oleh misi) akan sangat menyederhanakan proses anggaran. Program dan kegiatan beserta dengan indikator dan target yang telah ditetapkan dalam proses perencanaan diintegrasikan/diselaraskan dengan proses penganggaran kemudian dalam penganggaran dihitung jumlah uang yang harus digunakan tentunya tetap merujuk pada ASB dan standar satuan harga. Sehingga bisa dikatakan bahwa walaupun perencanaan dan penganggaran yang komprehensif tidak berpengaruh signifikan proses penyusunan anggaran berbasis kinerja tetap berjalan, asalkan proses penganggaran dengan perencanaan terintegrasi, juga dilaksanakannya monitoring dan evaluasi atas penganggaran dan pelaksanaan anggaran.

\section{Pengaruh monitoring dan evaluasi terhadap penyusunan APBD berbasis kinerja}

Hasil pengujian hipotesis ketiga menunjukkan bahwa pada variabel monitoring dan evaluasi, $t_{\text {hitung }}=7,307>t_{\text {tabel }}=1,99656$ sehingga monitoring dan evaluasi berpengaruh signifikan terhadap penyusunan APBD berbasis kinerja. Nilai koefisien regresi pertimbangan risiko audit hanya sebesar 0,746 menunjukkan jika pelaksanaan monitoring dan evaluasi baik akan meningkatkan penyusunan APBD berbasis kinerja. Hal ini sejalan dengan teori kebijakan khususnya tentang analisis kebijakan yang dikemukakan oleh Dunn (1981) yang menyatakan bahwa analisis kebijakan bertujuan untuk memberikan informasi, kritik, serta rekomendasi kepada para pembuat serta pelaksana kebijakan untuk menjalankan kebijakan dengan tepat, sehingga tujuan utama perumusan kebijakan, yakni untuk mengatasi permasalahan dapat dilaksanakan dengan baik. Dalam hal ini monitoring dan evaluasi pada pelaksanaan anggaran berbasis kinerja adalah salah satu cara untuk menjadi Check and Balance juga sebagai lesson learned dalam penganggaran tahun-tahun selanjutnya dan dalam pengukuran kinerja untuk mencapai visi dan misi Kepala Daerah.

\section{KESIMPULAN DAN SARAN \\ Kesimpulan}

Integrasi penganggaran dengan perencanaan dan tata kelola organisasi berpengaruh signifikan terhadap penyusunan APBD berbasis kinerja. Penyusunan APBD berbasis kinerja akan efektif apabila didukung dengan data yang terintegrasi, komitmen dari seluruh pemangku kepentingan dan alokasi anggaran yang disusun berdasarkan tugas pokok dan fungsi SKPD, dapat diidentifikasi sampai ke jenjang eselonisasi paling bawah. Perencanaan dan penganggaran yang komprehensif tidak berpengaruh signifikan terhadap penyusunan APBD berbasis kinerja. Hal ini karena indikator variabel yang menjadi inti pelaksanaan sistem yang komprehensif belum dilaksanakan dengan tepat. Monitoring dan evaluasi berpengaruh signifikan terhadap penyusunan APBD berbasis kinerja. Kegiatan ini dimaksudkan sebagai check and balance atas pelaksanaan rencana dan anggaran serta kinerja yang telah ditetapkan. Monitoring dan evaluasi berguna untuk memastikan bahwa suatu pelaksanaan program dan kegiatan tetap berjalan sesuai dengan jalur yang semestinya.

\section{Saran}

1. Meningkatkan dan memperhatikan integrasi perencanaan dengan penganggaran serta tata kelola organisasi. Penelitian ini memberi masukan kepada Pemerintah Kota Bitung Provinsi Sulawesi Utara untuk memaksimalkan pemenuhan integrasi perencanaan dengan penganggaran serta tata kelola organisasi. Salah satu upaya adalah dengan menggunakan informasi/data yang sama dalam proses perencanaan dan penganggaran, serta tetap berkomitmen untuk pencapaian target kinerja serta ikut bertanggungjawab dalam proses perencanaan dan pelaksanaan anggaran. 
2. Berupaya untuk menjalankan sistem perencanaan dan penganggaran yang komprehensif. Penelitian ini memberikan masukan kepada Pemerintah Kota Bitung Provinsi Sulawesi Utara untuk memaksimalkan sistem perencanaan dan penganggaran yang komprehensif terutama dengan membuat Analisis Standar Belanja (ASB) yang mendorong penetapan biaya dan pengalokasian anggaran kepada setiap aktivitas unit kerja menjadi ebih logis dan mendorong dicapainya efisiensi secara terus-menerus.

3. Meningkatkan pelaksanaan monitoring dan evaluasi. Penelitian ini memberikan masukan kepada Pemerintah Kota Bitung Provinsi Sulawesi Utara agar berupaya untuk meningkatkan pelaksanaan monitoring dan evaluasi sebagai sarana check and balance atas pelaksanaan rencana dan anggaran serta kinerja yang ditetapkan.

4. Bagi peneliti selanjutnya diharapkan dapat memperluas sampel penelitian, dengan mengambil sampel pada kabupaten dan kota yang ada di provinsi Sulawesi Utara.

5. Peneliti selanjutnya dapat mempertimbangkan menggunakan metode campuran kuantitatif dan kualitatif dalam penelitian, dimana metode kualitatif digunakan untuk menjelaskan hasil yang diperoleh dari metode kuantitatif sehingga dapat memperoleh kesimpulan yang sesuai dengan kondisi sebenarnya.

6. Peneliti selanjutnya diharapkan dapat mengembangkan kuesioner lebih lanjut mengenai faktor yang berpengaruh terhadap penyusunan APBD berbasis kinerja.

\section{DAFTAR PUSTAKA}

Australia National Audit Office (ANAO), 2008 Better Practice Guide : Developing and Managing Internal Budget.

Bastian Indra, 2006. Akuntansi Sektor Publik: Suatu Pengantar. Penerbit Erlangga. Jakarta

Edwards George C 1980, Implementing public policy (Politics and public policy series), Congressional Quarterly Press

Hananto Santoso Tri, Kurniasih Ramadhan L. A, Juliati 2013, Desain sistem penganggaran berbasis kinerja studi UNS, Seminar Nasional Sistem Informasi Indonesia 2014

Jensen, M. C and Meckling, W.H. 1976. Theory of the Firm : Managerial Behavior, Agency Costs and Ownership Structure. Journal of Financial Economics, Oktober, 1976.

Jones Charles O., 1977. An Introductions to The Study of Public Policy Massachuset, Duxbury Press.

Kementerian Keuangan Republik Indonesia 2014, Better Practice Guide Penganggaran Berbasis Kinerja

Osborne David and Gaebler Ted, 1992, Reinventing Government (New York: Plume, 1993)

Madjid Noor Cholis dan Ashari Hasan, 2013, Analisis Implementasi Anggaran Berbasis Kinerja (Studi Kasus pada Badan Pendidikan dan Pelatihan Keuangan), Kementerian Keuangan Republik Indonesia Badan Pendidikan dan Pelatihan Keuangan

Rahayu Sri, Ludigdo Unti, Afandy Didied 2007, "Studi Fenomenologis terhadap Proses Penyusunan Anggaran Daerah (Bukti Empiris dari Satu Satuan Kerja Perangkat Daerah di Propinsi Jambi)”, Simposium Nasional Akuntansi X

Shah Anwar and Shen Chunli, 2005. "Public sector Governance and Accountability series: Budgeting and budgetary institutions". edited by Anwar Shah. The World Bank, 1818 H Street, NW, Washington.

Sugiyono, (2014), Memahami Penelitian Kualitatif, Penerbit CV. Alfabeta Bandung

Utari Nuraeni, 2009. Studi Fenomenologis Tentang Proses Penyusunan Anggaran berbasis Kinerja pada Pemerintah Kabupaten Temanggung. Tesis Dipublikasikan Undip. 